\title{
PENGARUH TINGKAT PENGETAHUAN TENTANG BERLALU LINTAS, TINGKAT PENDIDIKAN DAN USIA TERHADAP MOTIVASI KEPATUHAN DALAM BERLALU LINTAS PADA WARGA
}

\author{
Endang Dwi Ningsih", Ni Ayu Rai Krishanandini R.D. ${ }^{2}$
}

\begin{abstract}
Background: Based on a WHO's research in 2011, traffic accidents are included among the top-10 of the death causes in Indonesia.

The traffic accidents are influenced by the knowledge lacks of the accidents impact for health. The proper traffic knowledge, education and age level of someone influences in motivation keeping safer and healthier themself by doing the right way on traffic. Regarding above, it is necessary to conduct a research about the effect of the traffic knowledge, education and age level on the motivation to compliance the traffic properly to the citizen.

Research Objective : to determine the influence of the traffic knowledge, education and age level on the motivation to compliance the traffic properly to the citizen.

Research Subjects : the study sampling of 200 peoples residing in the are of The Surakarta Traffic Department office by using Saturated sampling techniques.

Results : by the Bivariate test shows that there was an influence on the traffic knowledge level towards the obedience motivation in proper traffic $(p=0.000, p<0.005)$, there was no influence on the education level towards the obedience motivation in proper traffic $(p=$ $0.437, p>0.005)$, and there was an influence on the age level towards the obedience motivation in proper traffic $(p=0.000, p<0.005)$.

Conclusion : that the age variable and the traffic knowledge level were together influence toward the obedience motivation in proper traffic by $53,3 \%$ and the $46.7 \%$ remaining was influenced by other variables that have not been studied.
\end{abstract}

Keywords: The obedience motivation in proper traffic, the traffic knowledge level, the education and age level.

\section{PENDAHULUAN}

Berdasarkan penelitian dari WHO (World Health Organization) pada tahun 2011, kecelakaan lalu lintas termasuk dalam 10 besar penyebab kematian di Indonesia. Ada sekitar 30-40 ribu jiwa yang hilang pada tahun 2011 akibat kecelakaan lalu lintas. Hal ini menjadikan angka kematian yang disebabkan kecelakaan lalu lintas hanya berada di bawah angka dari penyakit jantung dan stroke sebagai penyebab kematian tertinggi di Indonesia. Untuk wilayah Jawa Tengah, data di Direktorat Lalu lintas POLDA JATENG menunjukkan bahwa pada tahun 2011 telah tercatat 20.159 kejadian kecelakaan lalu lintas yang menyebabkan 4.557 korban meninggal dunia serta menciderai hampir 26 ribu manusia. Selanjutnya pada tahun 2012 Direktorat Lalu lintas telah menerima laporan sebanyak 24.295 kejadian kecelakaan lalu lintas. Dari kejadiankejadian ini, 4.265 nyawa telah hilang dan lebih dari 35 ribu orang mengalami cidera. Angka-angka ini secara umum meningkat jika dibandingkan dengan tahun 2011 yang jika dilihat dalam hitung jam, maka pada tahun 2012 setidaknya setiap 2 jam ada satu orang meninggal dunia akibat kecelakaan lalu lintas (Kepolisian Daerah Jawa Tengah Direktorat Lalulintas, 2011). Ada beberapa faktor yang merupakan penyebab timbulnya kecelakaan yaitu manusia, kendaraan, sarana prasarana jalan 
dan lingkungan. Di antara empat faktor tersebut, faktor manusia merupakan faktor yang paling dominan sebagai faktor penyebab kecelakaan (85\%). Hal ini disebabkan oleh kurangnya kesadaran mereka akan pentingnya keselamatan berlalu lintas. Namun, kurangnya program-program yang terukur dari pemerintah serta sarana dan prasarana yang masih terbatas turut menyumbang tingginya angka kecelakaan lalu lintas yang terjadi (Kepolisian Daerah Jawa Tengah Direktorat Lalulintas, 2011).

Menurut data Satlantas kota Surakarta sepanjang tahun 2014 terdapat 576 kejadian kecelakaan lalu lintas, tahun 2015 terdapat 587 kejadian kecelakaan, dan tahun 2016 terdapat 754 kejadian kecelakaan lalu lintas. Dari data kecelakaan tersebut menunjukkan adanya peningkatan, khususnya pada korban yang meninggal dunia tahun 2014 terdapat 68 jiwa, tahun 2015 terdapat 71 , dan tahun 2016 ada 67 jiwa melayang akibat kecelakaan lalu lintas.

Berbagai model transportasi di era sekarang sudah semakin banyak macamnya ditambah dengan penunjang mobilitas yang semakin tinggi. Karena semakin banyaknya pengguna alat transportasi di jalan raya saat ini berdampak pada kepadatan lalu lintas, dimana transportasi paling banyak diminati adalah sepeda motor, dan kecelakaan lalu lintas juga paling banyak terjadi pada pengendara motor. Data globalisasi status report on road safety 2015 menunjukkan sekitar 1,25 juta yang meninggal dunia pada tiap tahunnya, karena kecelakaan lalu lintas merupakan penyebab kematian urutan ke delapan di dunia, diperkirakan pada tahun 2030 jika tidak dilakukan penanganan yang baik maka kematian akibat kecelakaan di jalan raya akan menjadi penyebab kematian nomor lima di dunia
(Perwitaningsih, Mahawati, dan Hartini, 2013).

Kecelakaan terjadi disebabkan oleh tindakan yang tidak aman (unsafe codition), yaitu dimana suatu perilaku atau kebiasaan tidak aman dari seseorang yang menimbulkan bahaya terhadap dirinya sendiri dan orang lain. Kondisi tidak aman (unsafe codition) adalah terdapat kondisi tidak aman yang dapat membahayakan seseorang (Perwitaningsih, Mahawati, dan Hartini, 2013).

Kecelakaan lalu lintas juga dipengaruhi akibat kurangnya pengetahuan tentang dampak dari kecelakaan untuk kesehatan. Pengetahuan tentang berlalu lintas yang benar akan memotivasi seseorang untuk menjaga dirinya menjadi lebih aman dan sehat dengan menghindari cara berlalu lintas yang tidak tepat. Kecelakaan lalu lintas merupakan salah satu masalah kesehatan masyarakat yang mempengaruhi semua sektor kehidupan. Kecelakaan terjadi pada setiap waktu dan bagi beberapa kelompok usia menyebabkan kematian tunggal. Maka pengetahuan dan tindakan masyarakat tentang pencegahan kecelakaan lalu lintas sangatlah penting karena jika pengendara motor mengetahui tentang bahaya kecelakaan untuk kesehatan mereka, maka masyarakat mungkin akan lebih berhati-hati dalam berkendaraan. Sebagaimana penelitian yang dilakukan oleh Chrussiawanti, Hapsari dan Fitriana (2014) yang berjudul: hubungan tingkat pengetahuan dan kepatuhan safety riding pada remaja SMAN 2 Sukoharjo dengan sampel sejumlah 142 orang dengan menggunakan tehnik purposive sampling, adapun alat uji yang digunakan adalah Spearman Rank Correlation memberi nilai korelasi sebesar 0,802 dengan $p$ value $=0,000<0,05$, artinya bahwa ada hubungan antara 
tingkat pengetahuan dengan kepatuhan safety riding.

Menurut Dimyati dan Mudjiono (2006) sebagaimana dikutip oleh Donsu (2017), motivasi dipandang sebagai dorongan mental yang menggerakkan dan mengarahkan perilaku manusia, Motivasi adalah serangkaian sikap dan nilai-nilai yang mempengaruhi individu untuk mencapai hal yang spesifik sesuai tujuan individu.

Praktik seseorang didasari oleh persepsi yang memunculkan suatu tindakan nyata atau sikap dalam berperilaku, baik atau buruk sikap seseorang bisa dipengaruhi oleh seberapa besar tingkat pengetahuan seseorang oleh karena itu maka suatu sikap atau tindakan yang baik sangat diperlukan dalam praktik keselamatan dan kesehatan berkendara, karena dalam berkendara yang aman diperlukan suatu respon yang cepat dan tepat sehingga pengendara bisa lebih tanggap akan lingkungan sekitar dan mencegah terjadinya kecelakaan lalu lintas (Perwitaningsih, Mahawati, dan Hartini, 2013).

Sebagaimana yang kemukakan oleh Arianto dan Arifin (2016), bahwa jumlah pelanggaran lalu lintas didominasi usia 21-30 tahun sebesar $43 \%$, sedang usia $17-20$ tahun sebesar $28 \%$, usia 31-50 tahun sebesar $20 \%$, usia kurang dari 16 tahun sebesar $6 \%$ dan sisanya usia lebih dari 50 tahun sebesar 3\%. Demikian halnya penelitian yang dilakukan oleh Khakim, Nurullita dan Meikawati (2016), yang menyatakan bahwa ada hubungan antara tingkat pendidikan, dengan perilaku Safety Riding, sedang untuk variabel umur, masa berkendaraan dan tingkat pengetahuan tidak ada hubungan. Adapun pada penelitian yang dilakukan oleh Rifal, Dewi dan Hartanti (2015), tentang faktor-faktor risiko yang berhubungan dengan kecelakaan lalu lintas pada pengemudi Bus PO Jember Indah dengan menggunakan uji regresi logistik dengan tingkat kepercayaan 0,05,hasil menunjukkan faktor tingkat pendidikan $p=0,019$ dengan $\mathrm{OR}=0,114 ;$ pengetahuan pengemudi $p=0,038$ dengan $\mathrm{OR}=$ 0,194 ; perilaku pengemudi $p=0,006$ dengan $O R=0,114$ dan faktor kendaraan $p=0,019$ dengan $\mathrm{OR}=$ 6,050 artinya bahwa faktor-faktor resiko yang berhubungan dengan kecelakaan lalu lintas adalah tingkat pendidikan, pengetahuan pengemudi, perilaku pengemudi dan faktor kendaraan.

Warga di wilayah Kasatlantas Surakarta sebagian besar yang sering berkendara adalah usia dewasa yang dari segi usia sudah matang maka peneliti tertarik mengetahui lebih dalam tentang pengaruh pengetahuan tentang berlalu lintas, tingkat pendidikan dan usia terhadap motivasi kepatuhan dalam berlalulintas pada warga di wilayah Kantor Lalu Lintas Surakarta.

\section{TUJUAN PENELITIAN}

Penelitian ini bertujuan untuk mengetahui pengaruh tingkat pengetahuan tentang berlalu lintas yang benar, tingkat pendidikan dan usia terhadap motivasi kepatuhan dalam berlalu lintas pada warga.

\section{DESAIN PENELITIAN}

Penelitian ini merupakan penelitian analitik dengan desain korelasi adalah penelitian yang mengkaji pengaruh tingkat pengetahuan tentang berlalu lintas, tingkat pendidikan dan usia sebagai variabel bebas (independent variable) dengan motivasi kepatuhan dalam berlalu lintas sebagai variabel terikat (dependent variable). 
POPULASI, SAMPEL DAN TEKNIK SAMPLING PENELITIAN

Populasi pada penelitian ini adalah warga yang datang ke Kantor Lalu lintas Surakarta. Sampel dalam penelitian ini adalah warga yang datang ke Kantor Lalu lintas Surakarta sejumlah 200 orang. Adapun tehnik pengambilan sampel dengan teknik quota sampling yaitu mengambil sampel yang didasarkan atas pertimbangan waktu sehingga dilakukan pembatasan.

\section{HASIL PENELITIAN}

Hasil penelitian ini dapat dipaparkan sebagai berikut :

Tabel 1. Karakteristik Responden

\begin{tabular}{|c|c|c|}
\hline Karakteristik & $f$ & $\%$ \\
\hline \multicolumn{3}{|l|}{ Jenis Kelamin: } \\
\hline Laki-laki & 113 & 57 \\
\hline Perempuan & 87 & 43 \\
\hline \multicolumn{3}{|l|}{ Kepentingan: } \\
\hline Mengurus SIM & 101 & 51 \\
\hline $\begin{array}{l}\text { Menyelesaikan } \\
\text { tilang }\end{array}$ & 99 & 49 \\
\hline
\end{tabular}

Dari tabel di atas menunjukkan bahwa sebagian besar responden berjenis kelamin laki - laki berjumlah 113 orang (57\%) dan jumlah responden berjenis kelamin perempuan berjumlah 87 orang (43\%). Sedangkan karakteristik berdasarkan faktor kepentingan ke Kasatlantas Surakarta adalah untuk mengurus SIM sebanyak 101 orang $(51 \%)$ dan untuk menyelesaikan tilang sebanyak 99 orang (49\%).
Tabel 2.

Distribusi Frekuensi

Variabel Penelitian

\begin{tabular}{|c|c|c|}
\hline Variabel & $f$ & $\%$ \\
\hline \multicolumn{3}{|l|}{ Tingkat Pengetahuan: } \\
\hline Tinggi & 164 & 82 \\
\hline Rendah & 36 & 18 \\
\hline \multicolumn{3}{|l|}{ Tingkat Pendidikan: } \\
\hline Tinggi & 170 & 85 \\
\hline Rendah & 30 & 15 \\
\hline \multicolumn{3}{|l|}{ Usia: } \\
\hline Dewasa & 174 & 87 \\
\hline Belum Dewasa & 26 & 13 \\
\hline \multicolumn{3}{|l|}{ Motivasi Kepatuhan: } \\
\hline Tinggi & 154 & 77 \\
\hline Rendah & 45 & 23 \\
\hline
\end{tabular}

Dari tabel di atas dapat diperoleh data bahwa:

1. Tingkat pengetahuan tentang berlalu lintas responden kategori tinggi sejumlah 164 orang (82\%) sedang kategori rendah sejumlah 36 orang (18\%).

2. Tingkat pendidikan responden kategori tinggi sejumlah 170 orang $(85 \%)$ sedang kategori rendah sejumlah 30 orang (15\%).

3. Usia responden kategori dewasa sejumlah 174 orang (87\%) sedang kategori belum dewasa sejumlah 26 orang (13\%).

4. Motivasi kepatuhan dalam berlalu lintas responden kategori tinggi sejumlah 154 orang (77\%) sedang kategori rendah sejumlah 45 orang (23\%). 
Tabel 3.

Tabulasi Silang tiap Variabel

\begin{tabular}{|c|c|c|c|c|}
\hline \multirow[t]{2}{*}{ Variabel } & \multicolumn{4}{|c|}{$\begin{array}{c}\text { Motivasi kepatuhan dalam } \\
\text { Berlalu Lintas }\end{array}$} \\
\hline & Tinggi & Rendah & Total & $p$ \\
\hline \multicolumn{5}{|c|}{ Tingkat Pengetahuan: } \\
\hline Tinggi & $\begin{array}{l}147 \\
(90)\end{array}$ & $\begin{array}{c}17 \\
(10)\end{array}$ & $\begin{array}{r}164 \\
(100)\end{array}$ & 0,000 \\
\hline Rendah & $\begin{array}{c}7 \\
(19)\end{array}$ & $\begin{array}{c}29 \\
(81)\end{array}$ & $\begin{array}{r}36 \\
(100)\end{array}$ & \\
\hline \multicolumn{5}{|c|}{ Tingkat Pendidikan: } \\
\hline Tinggi & $\begin{array}{l}130 \\
(77)\end{array}$ & $\begin{array}{c}40 \\
(23)\end{array}$ & $\begin{array}{r}170 \\
(100)\end{array}$ & 0.437 \\
\hline Rendah & $\begin{array}{c}24 \\
(80)\end{array}$ & $\begin{array}{c}6 \\
(20)\end{array}$ & $\begin{array}{r}30 \\
(100)\end{array}$ & \\
\hline \multicolumn{5}{|l|}{ Usia } \\
\hline Dewasa & $\begin{array}{l}147 \\
(85)\end{array}$ & $\begin{array}{c}27 \\
(15)\end{array}$ & $\begin{array}{r}174 \\
(100)\end{array}$ & 0.000 \\
\hline Belum & $\begin{array}{c}7 \\
(27)\end{array}$ & $\begin{array}{c}19 \\
(73)\end{array}$ & $\begin{array}{r}26 \\
(100)\end{array}$ & \\
\hline
\end{tabular}

Berdasarkan tabel di atas dapat dilihat bahwa :

1. Pengaruh tingkat pengetahuan terhadap motivasi kepatuhan dalam berlalu lintas : responden yang berpengetahuan tinggi sebanyak 164 orang, 147 (90\%) orang memiliki motivasi kepatuhan tinggi, 17 (10\%) orang memiliki motivasi kepatuhan rendah, sedang responden yang berpengetahuan rendah sebanyak 36 orang, 7 (19\%) orang memiliki motivasi kepatuhan tinggi, 29 (81\%) orang memiliki motivasi kepatuhan rendah. Berdasarkan hasil uji dengan menggunakan Chi Square dengan $\alpha=5 \%(0.05)$ diperoleh $\mathrm{p}=0.000$ menunjukkan bahwa ada pengaruh tingkat pengetahuan terhadap motivasi kepatuhan dalam berlalu lintas.

2. Pengaruh tingkat pendidikan terhadap motivasi kepatuhan dalam berlalu lintas: responden yang berpendidikan tinggi sebanyak 170 orang, 130 (77\%) orang memiliki motivasi kepatuhan tinggi, 40 (23\%) orang memiliki motivasi kepatuhan rendah, sedang responden yang berpendidikan rendah sebanyak 30 orang, $24(80 \%)$ orang memiliki motivasi kepatuhan tinggi, 6 (20\%) orang memiliki motivasi kepatuhan rendah. Berdasarkan hasil uji dengan menggunakan Chi Square dengan $\alpha=5 \%$ (0.05) diperoleh $\mathrm{p}=0.437$ menunjukkan bahwa tidak ada pengaruh tingkat pendidikan terhadap motivasi kepatuhan dalam berlalu lintas.

3. Pengaruh usia terhadap motivasi kepatuhan dalam berlalu lintas: responden dewasa sebanyak 174 orang, 147 (85\%) orang memiliki motivasi kepatuhan tinggi, 27 $(15 \%)$ orang memiliki motivasi kepatuhan rendah, sedang responden yang belum dewasa sebanyak 26 orang, 7 (27\%) orang memiliki motivasi kepatuhan tinggi, 19 (73\%) orang memiliki motivasi kepatuhan rendah. Berdasarkan hasil uji dengan menggunakan Chi Square dengan $\alpha=5 \% \quad(0.05)$ diperoleh $p=0.000$ menunjukkan bahwa ada pengaruh usia terhadap motivasi kepatuhan dalam berlalu lintas.

Hasil analisa multivariat pada penelitian ini menunjukkan variabel independen mempengaruhi variabel dependen dengan nilai Nagelkerke $R$ Square $53.3 \%$ artinya bahwa variabel usia dan tingkat pengetahuan secara bersama-sama berpengaruh terhadap motivasi kepatuhan dalam berlalu lintas sebesar $53.3 \%$ dan sisanya yang $46.7 \%$ dipengaruhi variabel lain di luar penelitian.

\section{PEMBAHASAN}

Berdasarkan Tabel 2 sebagian besar responden memiliki tingkat pengetahuan yang tinggi tentang berlalu lintas yaitu sebesar $82 \%$. Pengetahuan atau kognitif merupakan faktor yang sangat 
penting untuk membentuk tindakan seseorang, bahkan perilaku yang didasari oleh pengetahuan akan lebih langgeng dari pada yang tidak didasari pengetahuan (Wawan dan Dewi, 2011). Dari hasil uji bivariat dapat diperoleh $p=0.000$ dan $p<$ 0.05 artinya ada pengaruh tingkat pengetahuan tentang berlalu lintas terhadap motivasi kepatuhan dalam berlalu lintas, hal ini dapat dilihat pada tabel 3 dari 164 orang yang memiliki pengetahuan tinggi, $90 \%$ responden memiliki motivasi kepatuhan tinggi dalam berlalu lintas, hal ini karena pengetahuan terbentuk melalui proses yang terusmenerus yang setiap saat akan mengalami reorganisasi karena adanya pemahaman yang baru. Pengetahuan merupakan unsur utama pembentukan perilaku seseorang (Sunaryo, 2017) maka semakin tinggi tingkat pengetahuan semakin positif pula motivasinya yang akhirnya akan memunculkan perilaku yang positif. Semakin rendah pengetahuan responden dalam berlalu lintas, motivasi kepatuhan dalam berlalu lintas kategori rendah makin tinggi, hal ini dapat dilihat pada tabel 3 dari 36 orang yang tingkat pengetahuannya rendah terdapat $81 \%$ yang memiliki motivasi kepatuhan rendah dalam berlalu lintas.

Dari kutipan Sobur (2011), dinyatakan bahwa motivasi merupakan dorongan yang timbul yang tujuan akhirnya adalah perbuatan, sebagaimana yang disampaikan oleh Notoatmodjo (2012), pengadopsian perilaku yang didasari oleh pengetahuan dan kesadaran yang positif akan membentuk perilaku yang bersifat langgeng. Jadi bila tingkat pengetahuan semakin baik semakin baik pula motivasi kepatuhan responden dalam berlalu lintas.

Dari hasil penelitian yang dilakukan oleh Chrussiawanti, Hapsari dan Fitriana (2014) yang berjudul hubungan tingkat pengetahuan dan kepatuhan safety riding pada remaja SMAN 2 Sukoharjo memberi hasil $\mathrm{p}=0,000$ artinya bahwa ada hubungan antara tingkat pengetahuan dengan kepatuhan safety riding. Pada penelitian yang dilakukan oleh Colle, Asfian dan Andisiri (2016) yang berjudul faktor - faktor yang berhubungan dengan perilaku safety riding siswa SMAN I Wundulako Kabupaten Kolaka Halu Oleo menunjukkan hasil bahwa kepemilikan SIM $(p=0.04)$, pengetahuan $(p=0.023)$ dan dukungan keluarga $(p=0.002)$ artinya faktor yang berhubungan dengan perilaku safety riding adalah kepemilikan SIM, pengetahuan dan dukungan keluarga.

Dari uraian di atas maka tingkat pengetahuan berlalu lintas perlu terus ditingkatkan agar pengendara mampu memiliki kesadaran dalam berlalu lintas, sebagaimana yang dikemukakan oleh Perwitaningsih, Mahawati dan Hartini (2013), bahwa sekitar 1.25 juta orang meninggal tiap tahunnya karena kecelakaan lalu lintas yang merupakan penyebab kematian urutan ke- 8 di dunia. Maka salah satu upaya yang dilakukan Polri adalah menambah pengetahuan dan kemampuan diri serta menumbuhkan kesadaran para pengendara/pengemudi melalui pembinaan dan sosialisasi rambu-rambu lalu lintas (Hadiman, 2010).

Berdasarkan Tabel 2 tingkat pendidikan responden sebagian besar pada kategori tinggi (SLTAPT) yaitu sebesar $85 \%$. Sebagaimana yang dikemukakan oleh Adnani (2011), pendidikan adalah segala upaya yang direncanakan untuk mempengaruhi orang lain baik individu atau kelompok sehingga melakukan apa yang diharapkan oleh pelaku pendidikan. Pendidikan merupakan proses penyadaran yang terjadi karena interaksi berbagai faktor 
menyangkut manusia dan potensinya serta kemungkinankemungkinan yang terjadi (Mulyadi, Basuki dan Raharjo, 2016). Pendidikan terkait dengan daya dalam proses pembentukan budi pekerti, pikiran dan jasmani menuju tingkat kesempurnaan. Pendidikan terkait pula dengan proses pematangan intelektual, emosional dan kemanusiaan yang dilakukan terus- menerus (Warsini, 2015). Dari hasil uji bivariat dapat diperoleh $\mathrm{p}$ $=0.437$ dan $p>0.05$ artinya tidak ada pengaruh tingkat pendidikan terhadap motivasi kepatuhan dalam berlalu lintas, hal ini dapat dilihat pada tabel 3. dari 170 orang yang memiliki pendidikan tinggi terdapat $77 \%$ responden memiliki motivasi kepatuhan tinggi dalam berlalu lintas, dan yang pendidikan rendahpun juga memiliki motivasi kepatuhan dalam berlalu lintas tinggi $(80 \%)$. Sebagaimana disampaikan oleh Wawan dan Dewi ( 2011) bahwa makin tinggi pendidikan seseorang makin mudah menerima informasi, akan tetapi informasi yang diterima oleh seseorang terkait dengan pembentukan sikap tidak hanya dipengaruhi oleh pendidikan saja, ada banyak faktor yang terkait, antara lain lingkungan, sosial budaya, pengalaman pribadi, pengaruh orang lain yang dianggap penting dan media massa dan lain sebagainya. Pada penelitian yang dilakukan oleh Sadewa (2014), dengan judul pelanggaran lalu lintas oleh remaja pengguna sepeda motor di wilayah Surabaya, dengan responden remaja SMA Muhammadiyah I dan SMAN I Surabaya sejumlah 956 orang, menunjukkan hasil 54\% sering melanggar dan $23 \%$ selalu melanggar aturan lalu lintas, untuk tingkat pengetahuan diperoleh baik $58 \%$ dan sangat baik $28 \%$ serta untuk sikap melanggar tinggi 38\% dan sangat tinggi $21 \%$, maka dapat disimpulkan bahwa meskipun remaja memiliki tingkat pendidikan tinggi (SMA), tingkat pengetahuan baik/tinggi tetapi tetap memiliki sikap melanggar tinggi pula karena remaja cenderung melanggar aturan dan bersikap pemberontak.

Hasil penelitian ini, berbeda dengan penelitian yang dilakukan oleh Khakim, Nurullita dan Meikawati (2016) dengan judul hubungan umur, tingkat pendidikan, masa berkendaraan dan pengetahuan dengan perilaku safety riding (study pada pengendara ojek sepeda motor di Kelurahan Kedungmundu Kota Semarang) dengan hasil variabel umur $\mathrm{p}=0.407$, tingkat pendidikan $\quad \mathrm{p}=0.002$, masa berkendaraan $\quad p=0.487$ dan pengetahuan $p=0.810$ dengan kesimpulan bahwa ada hubungan tingkat pendidikan dengan perilaku safety riding dan tidak ada hubungan antara umur, masa berkendaraan dan pengetahuan dengan perilaku safety riding.

Berdasarkan Tabel 2 usia responden sebagian besar pada kategori dewasa yaitu sebesar $87 \%$ dan untuk usia yang belum dewasa sebesar $13 \%$. Sebagaimana yang dikemukakan oleh Potter dan Perry (2009) bahwa bila usia seseorang menginjak dewasa, yaitu $\geq 21$ tahun akan memiliki kemampuan berpikir kritis dan meningkat secara teratur, pendidikan yang diperoleh dan pengalaman hidup dapat meningkatkan konsep diri, kemampuan menyelesaikan masalah, ketrampilan motorik dan kesehatan emosi. Sedang bila pada usia yang belum dewasa akan mengalami masa transisi saat pubertas sampai masuk pada usia dewasa, akan mengalami pematangan biologis, disertai konflik fisik dan emosional. Hal ini diperkuat dengan persyaratan usia pengendara motor minimal 17 tahun, maka usia responden ratarata pada kategori dewasa. Dari hasil uji bivariat dapat diperoleh $p=$ 
0.000 dan $\mathrm{p}<0.05$ artinya ada pengaruh usia terhadap motivasi kepatuhan dalam berlalu lintas, hal ini dapat dilihat pada tabel 3. dari 174 orang berusia dewasa terdapat $85 \%$ responden memiliki motivasi kepatuhan tinggi dalam berlalu lintas, hal ini sejalan dengan yang disampaikan Wawan dan Dewi (2011), bahwa semakin cukup umur maka tingkat kematangan seseorang akan lebih baik.

Menurut hasil penelitian Bernice Neugarden, orang dewasa yang berusia antara 40 - 60 tahun adalah orang yang suka melakukan introspeksi dan banyak merenungkan tentang apa yang sedang terjadi dan ingin berbuat sesuatu dalam sisa waktunya artinya bahwa pada usia dewasa seseorang sudah memiliki kematangan emosi dan pola pikir (Desmita, 2015). Dari data tabel dapat diketahui bahwa responden kategori dewasa yang memiliki motivasi kepatuhan rendah ada 15\% sedangkan pada kategori belum dewasa yang memiliki motivasi kepatuhan rendah 73\%, maka dapat disimpulkan bahwa motivasi kepatuhan berlalu lintas salah satu faktornya, ditentukan oleh usia seseorang karena hal ini berkaitan dengan kematangan emosi dan pola pikir serta sikap pengendalian diri dalam berkendaraan. Sebagaimana penelitian yang dilakukan oleh Arianto dan Arifin (2016) dengan judul pengaruh usia, pendidikan dan budaya terhadap kepatuhan lalu lintas di wilayah hukum Polres Jepara menunjukkan hasil bahwa usia, pendidikan dan budaya secara bersama-sama berpengaruh terhadap kepatuhan lalu lintas di wilayah hukum Polres Jepara (nilai signifikansi $=0.000<$ dari 0.05)

Pada hasil penelitian ini, menunjukkan variabel independen mempengaruhi variabel dependen dapat dilihat dengan nilai Nagelkerke $R$ Square 53,3\% artinya bahwa variabel tingkat pengetahuan tentang berlalu lintas yang benar dan usia secara bersama-sama memberi pengaruh terhadap motivasi kepatuhan dalam berlalu lintas sebesar $53.3 \%$ dan sisanya yang $46.7 \%$ dipengaruhi variabel lain di luar penelitian. Pada usia dewasa responden yang memiliki motivasi kepatuhan tinggi sebesar $85 \%$ dan pada variabel tingkat pengetahuan yang tinggi yang memiliki motivasi kepatuhan tinggi sebesar $90 \%$, jadi usia dewasa dan pengetahuan yang baik akan memberikan pemahaman yang benar untuk memiliki kepatuhan dalam berlalu lintas, sebagaimana yang disampaikan oleh Wawan dan Dewi (2011) bahwa domain kognitif pada tingkat memahami akan memberi kemampuan untuk menjelaskan secara benar obyek yang diketahui dan mampu menginterprestasikan secara benar pula karena pengetahuan dan kematangan emosi merupakan domain yang sangat penting untuk terbentuknya tindakan seseorang. Hal ini diperkuat oleh pendapat Sudirman yang dikutip oleh Donsu (2017) bahwa apabila seseorang memiliki motivasi tinggi maka akan menjadi penggerak dari setiap kegiatan, memberi arah pada kegiatan yang harus dikerjakan sesuai rumusan tujuan dan sebagai seleksi untuk menentukan perbuatan apa yang harus dikerjakan. Adapun variabel lain yang belum diteliti memberi kontribusi sebesar $46.7 \%$ antara lain faktor budaya, lingkungan, masa berkendaraan, kondisi jalan, keadaan kendaraan, kosentrasi pengendara dan lain sebagainya.

\section{KESIMPULAN}

1. Ada pengaruh tingkat pengetahuan tentang lalu lintas yang benar terhadap motivasi kepatuhan dalam berlalu lintas $(p=0.000, p<0.005)$ 
2. Tidak ada pengaruh tingkat pendidikan terhadap motivasi kepatuhan dalam berlalu lintas $(p=0.437, p>0.005)$

3. Ada pengaruh usia terhadap motivasi kepatuhan dalam berlalu lintas $(p=0.000, p<0.005)$

4. Pada penelitian ini menunjukkan variabel independen mempengaruhi variabel dependen dengan nilai Nagelkerke $R$ Square 53.3\% artinya bahwa variabel usia dan tingkat pengetahuan secara bersama-sama berpengaruh terhadap motivasi kepatuhan dalam berlalu lintas sebesar $53.3 \%$ dan sisanya yang $46.7 \%$ dipengaruhi variabel lain yang belum diteliti.

\section{SARAN}

1. Perlunya pengetahuan tentang safety riding bagi masyarakat khususnya

pengendara/pengemudi motor agar mampu meminimalisir tingkat bahaya dan memaksimalkan keselamatan dalam Ialu lintas

2. Perlunya Polri terus melakukan pembinaan dan sosialisasi tentang rambu-rambu lalu lintas dalam rangka menambah pengetahuan, meningkatkan kemampuan diri dan menumbuhkan kesadaran tentang keselamatan berlalu lintas bagi masyarakat.

\section{DAFTAR PUSTAKA}

Adnani, Harizah. 2011. IImu Kesehatan Masyarakat. Nuha Medika, Yogyakarta.

Arianto, Dwi Agung Nugroho dan Samsul Arifin. 2016. Pengaruh Usia, Pendidikan dan Budaya terhadap Kepatuhan Lalu Lintas di Wilayah Hukum Polres Jepara. https://publikasiilmiah.ums.ac.i d. Diakses 9 Februari 2019.
Colle, Andi Balladho Aspat, Pitrah Asfian dan Wa Ode Sitti Nur Zalmariah Andisiri. 2016. Faktor-Faktor yang Berhubungan dengan Perilaku Safety Riding SMAN I Wundulako Kabupaten Kolaka. https:// media.neliti.com. Diakses 10 Februari 2019.

Chrussiawanti, Novita, Happy Indri Hapsari dan Rufaida Nur Fitriana. 2014. Hubungan Tingkat pengetahuan dengan Safety Riding pada Remaja di SMA Negeri 2 Sukoharjo. Digilib.stikeskusuma

husada.ac.id. jurnal pdf. Diakses 10 oktober 2018.

Desmita, 2015. Psikologi Perkembangan. Remaja Rosdakarya, Bandung.

Donsu, Jenita Doli Tine. 2017. Psikologi Keperawatan. Pustaka Baru Press, Yogyakarta.

Hadiman, 2010. Mengenal Lalu Lintas Sejak Dini. Amalia Bhakti Jaya, Jakarta.

Khakim, Rizal, Ulfa Nurullita dan Wulandari Meikawati. 2016. Hubungan antara Umur, Tingkat Pendidikan, Masa Berkendaraan dan pengetahuan dengan Perilaku Safety Riding di Wilayah Semarang. http:// lib unimus.ac.id. Diunduh tanggal 10 September 2018.

Mulyadi, Seto, Heru Basuki dan Wahyu Rahardjo. 2016. Psikologi Pendidikan: Dengan Pendekatan Teori baru dalam Psikologi. PT RajaGrafindo Persada, Jakarta.

Notoatmodjo, Soekidjo. 2012. Promosi Kesehatan dan Perilaku Kesehatan. Rineka Cipta, Jakarta.

Nurdin, Adnil Edwin. 2011. Tumbuh Kembang Perilaku Manusia. EGC, Jakarta. 
Panduan dan Etika di Jalan Raya. 2011. Kepolisian Daerah Jawa Tengah Direktorat Lalulintas. Semarang.

Perwitaningsih, Riyan, Eni Mahawati, dan Eko Hartini. 2013. Hubungan Antara Pengetahuan Dan Sikap Terhadap Praktik Keselamatan Dan Kesehatan Berkendara Sepeda Motor Pada Mahasiswa Kesehatan Masyarakat.

http://mahasiswa.dinus.ac.id/d ocs/skripsi/jurnal/.pdf. Diunduh pada tanggal 12 Oktober 2018.

Potter, Patricia A, and Anne G. Perry. 2009. Fundamentals Of Nursing. Salemba Medika, Jakarta.

Rifal, Akhmad David Casidy, Anita Dewi, dan Ismi Ragil Hartanti. 2015. Faktor Resiko yang Berhubungan dengan Kecelakaan Lalulintas pada Pengemudi Bus PO Jember Indah.

http://respository.unej.ac.id/bit stream/handle/.pdf. Diunduh pada tanggal 3 Oktober 2018.

Sadewa, Sandido Prinka. Pelanggaran Lalu Lintas Oleh Remaja Pengguna Sepeda Motor di Wilayah Surabaya. 2014.journal.unair.ac.id.

Diakses tanggal 11 Februari 2019.

Sunaryo, 2013. Psikologi Untuk Keperawatan. EGC, Jakarta.
Sunaryo, S. 2017. Hubungan Tingkat Pengetahuan Remaja Tentang Narkoba dan Sikap menggunakan Narkoba pada SMA di Kabupaten Sleman. Jurnal.stikes.wirahusada.ac.id. pdf. Diakses tanggal 10 Nopember 2017.

Sobur, Alex. 2011. Psikologi Umum. Pustaka Setia, Bandung.

Undang-undang lalu lintas dan angkutan jalan No 22 Tahun 2009. Pustaka Mahardika, Yogyakarta.

Warsini. 2015. Hubungan Jenis Persalinan, Tingkat pendidikan, Tingkat Pendapatan dan Status Bekerja Ibu dengan Keberhasilan ASI Eksklusif 6 Bulan di Kecamatan Baki Sukoharjo. Tesis. Surakarta.

Wawan, A. dan Dewi. M. 2011. Teori dan pengukuran Pengetahuan, Sikap dan Perilaku Manusia. Nuha Medika, Yogyakarta.

Widianti, E. 2007. Remaja dan permasalahannya: bahaya merokok, penyimpangan seks pada remaja dan bahaya penyalahgunaan narkoba. Available at: elib.unikom.ac.id/files/disk.pdf. Diakses tanggal 10 Oktober 2017.

\footnotetext{
${ }^{1}$ Dosen AKPER Panti Kosala Surakarta

${ }^{2}$ Mahasiswa AKPER Panti Kosala Surakarta
} 